\title{
Efficacy of micro-nutrients on growth and flower production of China aster [Callistephus chinensis (L.) NEES] cv. PRINCESS
}

\author{
Vipin Khilari Verma*, J. P.Verma, H. K. Verma and Rakesh Kumar Meena \\ Department of Horticulture, R.B.S. College, Bichpuri, AGRA(U.P.) INDIA \\ (Email : vipinkhilariverma@rediffmail.com)
}

\begin{abstract}
The field trials were conducted during winter season of 2002-2003 to study the efficacy of micro-nutrients on growth and flower production of China aster [Callistephus chinensis (L.) NEES] cv. PRINCESS in plot A-7 of the R.B.S. College Agricultural Farm, Bichpuri, Agra in Randomized Block Design with nine treatments i.e. $\mathrm{T}_{1}$ - Control (Spray of zinc sulphate 0.0 \%), $\mathrm{T}_{2}$ - (Spray of zinc sulphate $0.2 \%), \mathrm{T}_{3^{-}}$(Spray of zinc sulphate $\left.0.4 \%\right), \mathrm{T}_{4^{-}}$(Spray of ferrous sulphate $\left.0.0 \%\right), \mathrm{T}_{5^{-}}$(Spray of ferrous sulphate $0.2 \%), \mathrm{T}_{6}-$ (Spray of ferrous sulphate $\left.0.4 \%\right), \mathrm{T}_{7}-($ Spray of copper sulphate $0.0 \%), \mathrm{T}_{8}$ - (Spray of copper sulphate $\left.0.2 \%\right), \mathrm{T}_{9}-($ Spray of copper sulphate $0.4 \%$ ). It was observed that overall that maximum plant height was find out in treatment $\mathrm{T}_{5}(63.00 \mathrm{~cm})$, maximum diameter of main stem $(\mathrm{cm})$ was recorded in treatment $\mathrm{T}_{5}(3.09)$, maximum number of leaves was found in treatment $\mathrm{T}_{5}(125.40)$, maximum plant spread along and across the row $(\mathrm{cm})$ was found in treatment $T_{5}(38.34)$, maximum number of laterals was found in treatment $\mathrm{T}_{5}(31.44)$, maximum length of longest leaf $(\mathrm{cm})$ was found in treatment $\mathrm{T}_{5}(10.69 \mathrm{~cm})$, maximum width of the longest leaf $(\mathrm{cm})$ was found in treatment $T_{5}(7.34 \mathrm{~cm})$, maximum green weight of plant canopy at final was found in treatment $T_{5}(401.25)$, maximum dry weight of plant canopy at final was found in treatment $T_{5}(72.39)$, maximum date of visibility of flower bud was found in treatment $T_{5}(131.33)$, maximum date of colour break was found in treatment $T_{5}(139.29)$, maximum date of full blooming was found in treatment $\mathrm{T}_{5}(160.07)$, maximum date of harvesting of floral heads was found in treatment $\mathrm{T}_{5}(162.18)$, maximum fresh weight of floral head $(\mathrm{g})$ was found in treatment $\mathrm{T}_{5}(4.96)$, maximum length of floral head $(\mathrm{cm})$ was found in treatment $\mathrm{T}_{5}(3.20 \mathrm{~cm})$, maximum width of floral head $(\mathrm{cm})$ was found in treatment $\mathrm{T}_{5}(6.21 \mathrm{~cm})$, maximum length of floral stalk $(\mathrm{cm})$ was found in treatment $\mathrm{T}_{5}$ $(21.67 \mathrm{~cm})$ and maximum diameter of floral stalk $(\mathrm{cm})$ was found in treatment $\mathrm{T}_{5}(0.27 \mathrm{~cm})$.
\end{abstract}

Key Words : Copper sulphate, Growth, China aster, Zinc sulphate, Ferrous sulphate

View Point Article : Verma, Vipin Khilari, Verma, J.P., Verma, H.K. and Meena, Rakesh Kumar (2018). Efficacy of micro-nutrients on growth and flower production of China aster [Callistephus chinensis (L.) NEES] cv. PRINCESS. Internat. J. agric. Sci., 14 (1) : 160-164, DOI:10.15740/HAS/IJAS/14.1/160-164.

Article History : Received : 21.07.2017; Revised : 25.11.2017; Accepted : 08.12.2017

* Author for correspondence: 